\title{
ЛИРИЗАЦИЈА ИСТОРИЈЕ У \\ ПРИПОВЕЦИ РАДОВАНА \\ БЕЛОГ МАРКОВИЋА „МЕЛИТА, \\ КОВЧЕЗИ, ОСТАЛО”
}

Завод за уџбенике

Апстракт: Предмет анализе у овом раду јесу елементи политичког дискурса, поступци приповедања, лиризација, функције стилских фигура и библијске симболике у приповеци Радована Белог Марковића „Мелита, ковчези, остало”. Ово је једина његова приповетка која као један од главних мотива садржи погром Јевреја у окупираној Србији за време Другог светског рата, и одликује се специфичним начином компоновања, структурним и стилским карактеристикама, које се у раду сагледавају методама дескриптивно-аналитичког карактера. Неке од таквих карактеристика су: синтаксичка инверзија, употреба музиколошке терминологије, релативизација реалистичности дела приповетке, стилске фигуре и др.

Кључне речи: погром, Јевреји, Други светски рат, политички дискурс, лиризација, глисандо, фуга, приповедање, стилске фигуре, гротеска

Приповетка „Мелита, ковчези, остало”, први пут објављена у збирци Црни колач (1983. године'; пагинација се наводи према Сабраним gелима, 2013/4: 81-90)², једина је у опусу Радована Белог Марковића која као један од главних мотива има погром Јевреја у Другом светском рату у окупираној Србији.

Разлози због којих је она занимљива проучаваоцу књижевности су бројни. Неки од њих су:

\section{1 Ваљево: „Милић Ракић”.}

2 Постоји више стилских разлика између првог издања ове приповетке и „коначног”, из Сабраних gела. На пример, у овом издању уведен је сегмент којим је указано на значај породичне традиције (,jа као ја само по имену, које је због болих обичаја и само било дедино"; 82; курзив изворни). Такође, додат је и део којим је комплексније указано на јунаково психичко стање (аутокарактеризација), страх од смрти подстакнут друштвенополитичким догађајима; у тексту уочавамо директну алузију на смрт, дата је персонификована слика смрти („да ће неко доћи с капуљачом преко лица”; 83). Тај додати део јесте и у функцији лиризације прозног текста, што је постигнуто инверзијама на синтаксичком нивоу („о клинове окачених”; „радњу мимоходећи”; „у коси односим"; 82-83). У последњем издању, такође, у текст се уводи поређење и укида

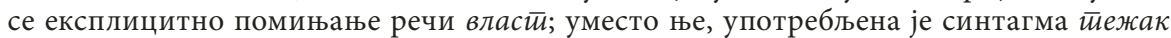
немачки йишйоль (84). За разлику од првог издања (стр. 207-208), писац местимично укида и инверзије на синтаксичком нивоу, као да тиме жели да укине лиризацију прозног текста (стр. 86-87). И на целој 88. страни, у књизи IV, у оквиру Сабраних gела, изостају инверзије на синтаксичком нивоу. 
- садржи елементе политичког дискурса, а исприповедана је у лирском тону;

- приповедач се служи музичким терминима у функцији дочаравања атмосфере у самој приповеци - глисандо, фуга;

- уколико размотримо све њене објављене верзије, писац настоји да саму структуру приповетке прилагоди особеностима наведених музичких облика, нарочито последњу објављену верзију;

- функција оквира ове приповетке (који постоји у последњој објављеној верзији у сабраним делима, а која у свим претходним верзијама не постоји) јесте лиризација, тј. приближавање самих оквира приповетке песничком тексту;

- поступци којима се писац служио како би свом приповедању дао лирски тон, употреба стилских фигура, пишчеве интервенције на синтаксичком плану;

- поступак превођења приповетке с реалистичном основом у сферу зачудног и мистичног;

употреба гротеске и њена функција у овој приповеци;

библијска симболика;

употреба каталога у датој приповеци и његова функција;

реализација политичког дискурса;

- ова приповетка представља значајно подсећање на трагичне историјске догађаје, који у њој постају детерминанта, а не нарушавају њену лепоту због начина на који је о њима приповедано;

- из ове приповетке могу се, на основу удеса појединаца, обичних људи, о значајним историјским догађајима стећи трајна знања, као из релевантног уџбеника историје.

„Интимно језгро” (Зуровац, 1986: 36) приповетке Мелий ковчези, осйало јесте погром почињен над Јеврејима у окупираној Србији током Другог светског рата. Тада је у немачким концентрационим логорима (Judenlager) на тлу Србије (Топовске шупе, Старо сајмиште итд.) и другде побијено више од две трећине српских Јевреја (преко 16.000).

Ова приповетка, исприповедана у 1. лицу, заснива се на ретроспекцији јунака приповедача о трагедији Јеврејке Мелите, која је одведена у логор, али и о његовим личним трагедијама (смрт чланова шире и уже породице, Мелитино одвођење у логор) условљеним друштвенополитичким околностима. С обзиром на то да је у приповеци реч о појединачним судбинама, личним историјама малих људи, у односу на општу, уочава се да нигде нису употребљене лексеме: погром, холокауст, концлогор, душегубка (гасна комора), истребљење и сл.

Дакле, једина приповетка Радована Белог Марковића, чија је тематска основа страдање Јевреја у Другом светском рату на тлу Сp- 
бије, садржи елементе политичког дискурса, а исприповедана је у лирском тону. Приповедач је два пута употребио и музичке термине у функцији дочаравања атмосфере у самој приповеци - глисандоз: „Сутрадан, готово y glissandu, нестају још два ковчега...” (87) и фуга 4 :

Не бих да ми се ико подсмева, али треба се, ипак, вратити на почетак ове приче, ради оног зрикавца, с крова станичне зграде, или из самих њених темеља, који је, до пред саму јесен, давао бело, уносећи неку сталност у фугу тог лета: упркос пуцњави у брдима и неподмазаним вратима која су цвилела за сваку ситницу (90).

Стога би требало да уочимо везу између тих термина и начина компоновања приповетке, с обзиром на то да је приповедач у последњој објављеној верзији одабрао баш њих 5 .

Оно што констатујемо на основу таквих анализа јесте да приповетку чини низање појединачних, међусобно сличних, трагичних догађаја који се одвијају брзо, један за другим, скоро сливено, клизајуће, као у глисанду и они су готово имитација један другог, што је карактеристично за фугу (после сваког нестаје по један ковчег из излога мртвозорничке радње).

Последња објављена верзија приповетке има и специфичан оквир. Њу затвара ауторски коментар, већ наведени цитат у којем је поменута фуга (Марковић 2013/4: 90). У првој објављеној верзији изостаје оквир који затвара приповетку. На основу тога закључујемо још једну композициону сродност ове приповетке с фугом. Наиме, фуга увек има експозицију, док њен завршни део (orgelpunkt) може да постоји, али није обавезан. У првом издању ове приповетке он је заиста изостао, али га је писац дописао у последњој верзији. Његова функција јесте да уоквири приповетку, а с обзиром на то да је реч о

3 „ГЛИСАНДО (франц. Glisser, клизити), брзи прелаз са једног тона на други изводећи при томе и све тонове између њих." (Лексикон музичке уметиносиичи, 1972: 161)

4 „ФУГА, полифони облик инструменталне или вокалне, одн. вокално-инструменталне музике са јеgном, gве, итри или четиири теме. Најчешћи облик Ф. је са јеgном тиемом,

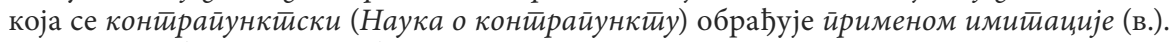
Постоје одређена правила формалне изградње Ф., нарочито у њеном почетку и на завршетку. Почетни део Ф. зове се ексӣозиција, средњи - развојни gео (или gруїа йровеgба $\bar{u} е м е)$, а завршни део - оріелйункіи, са или без коge (coda). Овај последњи део није обавезан." (Лексикон музичке уметности, 1972: 150)

5 У првом издању приповетке Мелитй, ковчези, остиало, уместо музичког термина ілисанgo, био је употребљен музички термин стиакайо. Уколико упоредимо значење музичког термина ілисанgо са значењем музичког термина сииакайо („СТАКАТО [итал. Staccato], начин певања и свирања којим се тонови изводе невезано, издвојено и скраћено, као да међу њима постоје паузе" (Лексикон музичке уметиносйи, 1972: 559)), уочићемо, у ствари, да је аутор пронашао примеренији музички термин који прецизније одређује његов приповедачки поступак и структуру своје приповетке, ритам смењивања догађаја о којима се приповеда, јер њих не карактеришу неповезаност и издвојеност, што је карактеристика стаката, већ повезаност, сличност, сливеност и брзо смењивање, што је карактеристика глисанда. 
ауторском коментару, његову функционалност видимо и у томе да је у њему експлицирана чињеница да је приповетка компонована по угледу на фугу.

Функција оквира ове приповетке јесте и лиризација, тј. приближавање самих њених оквира песничком тексту, као и релативизација реалистичности осталог дела приповетке - погром Јевреја и други трагични догађаји, условљени друштвенополитичким околностима. Они се преводе у сферу зачудног и мистичног јер се, како је већ наведено, зрикавац с почетка, али и с краја приповетке, упркос свему, као контраст стварности, приповеданом времену, оглашава „с крова станичне зграде, или из самих њених темеља”.

Приповетка чија је основа реалистична, прожета је и извесним исказима који се у самој причи одликују незнатним варијацијама и за које можемо рећи и то да су у функцији рефрена: „Јун, или јул. Вероватније: сам почетак августа.” (81) [...]; „Јун, или јул, мада је ова прича могућна и у августу” (86); „Јун, или јул. Можемо се приклонити и августу...” (88); „Јун, или јул, мада је све то без икаква значаја” (89).

Ово стилистичко понављање истовремено је и израз приповедачевог метафизичког става, поготово имајући у виду трећи исказ („мада је све то без икаква значаја”), да ништа што се у свету и животу догађа није суштински важно. Ако се и чинило да нешто може имати смисла, постаје обесмишљено чињеницом о смрти као константи. У датој приповеци смрт (вољене особе) потврђује метафизичку чињеницу, а последица је великих историјских удеса (који у основи имају глобалне друштвенополитичке промене) који заувек мењају приповедачев свет.

Осим овог, до сада једног наведеног, у приповеци уочавамо и низ других ауторских коментара. Приповедач коментарише приповедачки поступак и образлаже његову функцију. Служи се контрастом у функцији сликања драматичности друштвенополитичких дешавања и посебности атмосфере лети а уојем се чују зрикавци, док се саิмо лето изједначава с фүі̄oм - музичким обликом карактеристичним по смењивању гласова. Дакле, смењују се „пуцњава” и „зрикавци”, а на тај начин ометен је ток мирнодопског, устаљеног живота.

Оквир приповетке, поготово утврђен злослутном „пуцњавом у брдима”, увод је у одмазду окупатора над цивилним становништвом, која ће тек уследити. У вези с тим, подсетимо се наредбе „опуномоћеног командујућег генерала за Србију”, Франца Бемеа (Franz Böhme), издате 10. октобра 1941. године: за рањеног немачког војника стрељати педесет српских цивила, а за убијеног сто Срба. Активирање политичког дискурса у овој причи алузија је на наведену наредбу, а исказана је симболички - најезgом їубара - пошашћу природе пред којом је појединац немоћан, као што је немоћан и пред 
друштвенополитичким манифестацијама насиља организоване силе: „Јун ил’ ће бити јул. Вероватније, сам почетак августа. Година, можда, није ни била, али диња је било, празника и оголелих грана иза најезде губара" (81).

Део те пошасти јесте и Недићева Срйска gржавна ситража', која се такође помиње у приповеци, а која, између осталог, претреса станове грађана, о чему је у приповеци приповедано, као и о потрази за припадницима покрета отпора и о хапшењу Јевреја... Све наведено садржано је у микросвету приповедачеве тетке:

Јун, или јул, мада је ова прича могућна и у августу и неће јој наудити спомињање звезда-падалица, ни диња, ни мува, ни описивање уличног призора са смрдљивом рибљом главом, у каналу, пред Управом града чија врата чува задригли ваљевски геак; утегнут у нови орнат Српске државне страже, не доспевши ни картицу с магацинским бројем да отргне, него му је висила с оковратника. Шта још може да се каже? Све приче иду кривудавим путем, кроз сећање, али се може узети да сунце пригрева и спарушује оне погребне цикламе и листове мушкатли, док тетка усредсређено разгледа свилену чарапу, а онда кроз плач говори: 'Рупа се појавила, опет!' (86)

Припадници СДС-а карактерисани су у причи употребом ироније и гротеске, као и на основу њихових поступака: „задригли ваљевски геак, утегнут у нови орнат Сриске gржавне сиираже, не доспевши ни картицу с магацинским бројем да отргне”. Они врше претрес теткиног дома:

Шопенхауера помињу, четнике, философију налажење сродне душе, осећај празнине и, у два наврата, полни орган мушки. Гласно се и много смеју. Тетка из фраса у фрас пада, валеријан иште. [...] Очев војнички сандук затим раскивају, у лудом узбуђењу, као да се неко пијан вратио кући. Наредник Оровић изгледа као човек који врло добро зна шта све може поседник тешког немачког пиштоља, а ипак ме удара шаком преко лица. [...] Сутрадан је поручник Милосављевић скрупулозно прднуо и, уз извињење учтиво и тихо, а тетка је изнела неколике шкатулице с помадама, уз напомену да је из свих помада давно исхлапила тужна слутња ноћних чаролија, због опште зарђалости доба $(82 ; 84)$.

У наведеној слици репресије Недићеве Срйске gржавне сйраже, доводећи поступке њених припадника до гротеске, уочавамо да

6 После слома Југословенске војске, Берлин је захтевао да се у крњој Србији формира влада која би била одговорна за ред и мир, и водила рачуна о снабдевању храном немачке окупационе силе. Тако је 28. августа 1941. године формирана српска влада на челу с генералом Миланом Недићем. Срйска gржавна сииража (скраћено СДС) била је организациона полицијско-војна јединица Министарства унутрашњих дела, од 3. марта 1942. до октобра 1944. године. Обављала је полицијски посао који је подразумевао одржавање јавног реда и мира, привођење преступника, разбојника, убица и других криминалаца. СДС је такође активно учествовала у хапшењу Јевреја, Рома и Срба родољуба, које је испоручивала немачким нацистима на погубљење. 
се приповедач служио бројним контрастима, као и дескрибованом ситуацијском комиком. Тако је постигнут комичан ефекат: „Сутрадан је поручник Милосављевић скрупулозно прднуо, уз извињење, учтиво и тихо".

Наведена дешавања у теткином дому чине један ток приповетке, а други, њен паралелни ток, који је заправо окосница читаве приповетке, јесте љубав јунака приповедача према Јеврејки Мелити и његова патња због њеног страдања:

Али не обазирем се ни на тетку, ни на догађаје. Мелити одлазим, кроз прашину и по млаком ветру, сваког дана, да је видим и да јој по једну књигу однесем, а понекад и цвет бели. Сањарио сам да ћу, једном, сјахати с коња у њеном каменом дворишту и да ће ми она махати с прозора, увек мало болесна, док прибирам пешеве црне пелерине, по прашини и по млаком ветру. [...] Поручник Милосављевић самоуништењем прети, док под кошуљом ћутим врелину Мелитина длана. [...] Све теже је за брашно и маст, на улицама је све више паса који се ни погледом не смеју узнемирити, а ја Мелиту упркос свему волим: врелу њену руку с материним прстеном и чудноватом сребрном бразлетном, мале груди у мрежи плавих вена, бело колено. Травом је проникао праг кућерка њеног, нико јој осим мене не долази $(82 ; 83 ; 85)$.

На основу наведеног уочавамо низ лирских елемената који овај сегмент приповетке, с реалистичном основом, у којој се приповеда о конкретном историјском удесу који је условио велике индивидуалне несреће, несреће појединаца, приближава поезији. Најпре уочавамо рефренску функцију варијација појединих синтагми. Њима је дочарана и атмосфера приповеданог времена која потенцијално наговештава психичко стање или расположење јунака. Потом уочавамо инверзију на синтаксичком нивоу. Било би очекивано да у прози исказ: „Мелити одлазим сваког дана, кроз прашину и по млаком ветру, да је видим и да јој по једну књигу однесем, а понекад и цвет бели” гласи: „Одлазим Мелити сваког дана, кроз прашину и по млаком ветру, да је видим и да јој однесем по једну књигу, а понекад и бели цвет”. Разлика коју уочавамо у тој реченици у односу на ону која би за прозни исказ била уобичајена имплицира важност стилистичког избора аутора и његову, сасвим јасну, стваралачку намеру. Синтаксичком инверзијом истиче се фокус (Мелита), док се пребацивањем конгруентног атрибута иза управне именице у први план истиче особина изражена атрибутом. Наведени пример такође представља потврду, једну од бројних, да Радован Бели Марковић спада у ред највећих песника међу српским прозаистима и да је према језику, како је констатовао Радивоје Микић, скрупулозан попут песника.?

7 „Радован Бели Марковић је, још у књизи Паликућа и Тереза милостии йуна, показао да врло пажљиво бира лексику и још пажљивије склапа реченицу (у наредним њего- 
У приповеци уочавамо и функционалност контраста - с једне стране, глад и страх јунака приповедача да буде кажњен што поceћује Јевреје, а на другој, врелина Мелитиног длана коју осећа под сопственом кошуљом. Дакле, и овај поменути пример доказ је и присуства лирског у прози Радована Белог Марковића.

Релевантна је и употреба симбола у датој приповеци - чизама. У њој су оне вишеструко персонификоване. Тај симбол у Мелити и најпре је симбол наде у очев повратак - јер отац је - $y \delta p g u м a:$

Узлетаху мавена ${ }^{8}$ јата, а очеве охоле и посвађане чизме још су труптале ходником. Високе очеве чизме, пар потоњих чуда која сведоче за њ и повратак његов изглеђују. Црне чизме, које су само на његовим ногама могле да остану у истој соби (премда је увек било време да оду одавде!) и о којима би требало дуго и понаособ говорити, а и застајати пред њима, баш као и пред тајанственим ормарима трокрилним, за чије браве, у светској тмуши негде, мора постојати зарђалих кључева свежањ, окачен о жебељу9 криву (81).

У последњој реченици овог навода такође уочавамо инверзије на синтаксичком нивоу у функцији лиризације прозног текста („зарђалих кључева свежањ, окачен о жебељу криву"). У претходном цитату такође је употребљен поступак инверзије у функцији лиризације („да јој по једну књигу однесем, а понекад и цвет бели”; 82); али, диксурзивно много значајније јесте да чизме потом, у даљем току приповетке, постају симбол спровођења рейресије, као и симбол понашања политичких и војних моћника (Недићеве Срйске gржавне cīpaжe). Закључујемо да је политички дискурс реализован управо увођењем симбола чизама које су истовремено и персонификоване у функцији појачавања сугестивности приповеданог: „Елем, старе чизме трупћу ходником, тумара празна кабаница, преметачине нам врше, грубо нас буде, тетку штипају" (81).

Именичке синтагме у реченицама „старе чизме трупћу ходником” и „тумара празна кабаница” јесу примери метонимије, односно синегдохе, а истовремено су и елементи фантастике у приповеци чија је основа реалистична. Наведеним фигурама постигнута је и сугестивност приповеданог, а дочарана је и гротескност читаве атмосфере у којој се одвија репресија над грађанима. Приповедач се служи и иронијом у функцији карактеризације сарадника, тј. службеника актуелних власти: „Лиферанти се појављују; носиоци строгих бркова...” (81).

У тексту такође уочавамо и спајање неспојивог, својеврсну контрадикцију, што је у функцији онеобичавања приповеданог, као и у

вим књигама то је још изразитије, што нам даје за право да кажемо да је реч о врло великом артисти, прозном писцу који је према језику скрупулозан на онај начин на који су према њему скрупулозни прави песници).” (Микић 2013: 7-8)

8 Мавен - голубије плав.

9 Жебель - клин. 
функцији дочаравања психичког стања јунака. С обзиром на то да се услед ратних околности трагични догађаји веома брзо смењују, као и на чињеницу да рат подразумева стање измењене свести свих који су се у рату нашли ${ }^{10}$, делује и као да се и проток времена изменио, убрзао. У таквом његовом протоку јасније се уочава разлика између оног што је првенствено политичко и онога што припада емотивном свету појединца: „Дани некако пролазе, тумбају се један преко другог, а деси се да између изласка и заласка сунца пролете и три дана" (83).

О погибији оца у брдима - јер отац је припадник покрета отпоpa, што је кључни разлог преметачине теткине куће - приповедано је, али готово у сенци у односу на приповедање о емотивном свету јунака приповедача, у којем запажамо и поступак аутокарактеризације. Психичко стање јунака приповедача дочарано је, између осталог, и употребом контраста („вреле главе и хладног тела”) и поређења:

Стрепње неодређене пун, због пуцњаве у брдима, вреле главе и хладног тела, [...] мимоходим излог погребника Јована и пет ковчега у излогу, међу свећама високим и плавим. [...] Од себе мада бескрајно далеко, мада занесен и мргодан као да су ме простачки штипали, увиђам где недостаје, у излогу Јованове радње, ковчег један, велики и црн, за велике и важне људе. / У њ сутрадан полажемо оца. Убили га у брдима (82; 85).

Мелитино страдање - одвођење у логор - најпре је наговештено изузетном лирском сликом. Не треба апстраховати ни чињеницу да се оно догодило ноћу: „Исте ноћи, једна се звезда дуго распрскавала, па је читаво небо, и најглупљима, треном заличило на Мелитину муслинску реклу, осуту жутим цветовима. Знао сам и потрчао сам" (87).

Само доба ноћи, мрака, а посредно и мрачност самог догађаја, дочарани су најпре узастопном употребом именице мрак на почетку сваке реченице, који има функцију анафоре, а потом и употребом поређења и, на крају - контраста:

Мрак, као у рукаву старе кабанице. Мрак, као у дну очеве чизме, оне која је била лева и која није била старија од неколико каљавих месеци, а изгледала је као да иза себе има руску степу и најмање тридесет зима. Мрак, за оне слабих живаца који би да се сакрију и вриште. Мрак, који осигурава намицање завеса на свим прозорима, док Мелиту на север одводе. Мрак, као скорео пекмез од шљива. Мрак, с муком избегаван у мојим сећањима, у којем се бели само Мелитино раме (87).

Рекла је лексема која означава део традиционалне ношње -

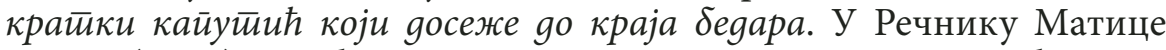
српске (РМС) уз дефиницију лексеме рекла наводе се квалификато-

10 „Другом светском рату је остављено да 'обогати психопатологију маса' (ако се тако сме варирати наслов Ле Бонове књиге): прво тиме што нас је обдарио 'ратом живаца', а друго тиме што нас је обавестио о доживљајима из концентрационих логора." (Франкл 1994: 21) 
ри: нем. и варв. ${ }^{11}$, што такође маркира употребну вредност наведене речи, као одевног предмета припаднице јеврејског народа. У наведеној лирској слици доминира „Мелитина муслинска рекла, осута жутим цветовима”. За приповедача рекла „осута жутим цветовима” нарочито је важна зато што је она била договорена „јавка” међу љубавницима, „знак да ме (Мелита - С. И.) чека”, ако је рекла „окачена понад прозора” (85). Тако је специфичан одевни предмет у приватној историји тог пара израстао у симбол њихове љубави.

У приповедању о ноћи депортације уочавамо и једну асоцијацију на библијски догађај, тј. библијску причу. Као упозорење на наступајући злочин - једна се „звезда дуго распрскавала, па је читаво небо, и најглупљима, треном заличило на Мелитину муслинску реклу”. Према Јеванђељу по Матеји (2:2), Витлејемска звезда („звезда са истока"), која се ненадано појавила на небу, повела је три мудраца ка месту рођења Исуса Христа. Поређење озвезданог неба и Мелитине рекле, у овој приповеци, заправо је начин да приповедач укаже на судбоносност тог знака, знака да младић мора одмах кренути у спасавање своје јеврејске девојке. Али, спаса нема, и тај гробни и свеобухватни мрак, који доминира, симбол је мрачности света, жалости и гнушања над почињеним злочином.

Након констатације да је изашла „објава Да се у руйама крај изи-

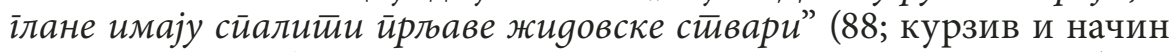
писања изворни), детаљно се приповеда о месту на ком је објава истакнута. У тој функцији, у последњој верзији приповетке, употребљено је поређење:

[...] лепљеној по свим капијама, с наглашеним торжеством, као да ће у наш градић, далеко од сваке воде, пристати велика бела лађа, са слоновима, жирафама, црнцима, безобзирним коњушарима, њиховим господарицама у јахаћим сукњама и господарима који се сажаљиво смеше девојанама из гимназијског хора, одабраним да их певањем дочекају, уз букет модрих перуника, с листовима који су личили на двосекле зелене ножеве (88).

У приповеци се са иронијским отклоном приповеда о лепљењу окупаторских наредби које јунака приповедача асоцирају на лепљење плаката за долазак циркуса у варош. Иронија се потом трансформише у гротеску која је употребљена у функцији сликања доласка „државне” кочије („карете”, каруце) коју - вуче магарац ${ }^{12}$, како би њоме биле одвезене ствари депортованих Јевреја:

11 Нем. је етимолошки квалификатор који указује на позајмљеницу из немачког језика, а варваризам означава реч страног порекла, обично застарелу, која се не употребљава у стандардном језику. Као потврду за значење овај речник наводи пример из књижевног опуса Исидоре Секулић. У Вуковом Рјечнику такође је забележена лексема рекла, уз занимљиву напомену да ју је забележио у Војводини („у војв.” - у војвоgсйву) (Караџић 1852).

12 „Чула се далека и потмула грмљавина и по томе се могло познати да, уместо беле лађе, стиже државна карета, коју магарац вуче а нарочити службеник прати, калдрмом по којој се ни поглед није могао померати без приличне ларме, а камоли тешко оковани точкови” (88). 
Утоварају прво јорган, надуту стару крпу боје усирене крви. По прашини се вуче приперак извешчалог чаршава. Црна рукавица пада пред излогом апотеке. Камена Хигија као да очекује неког ко би ту рукавицу између два прста узео. Док прслучић боје бресквиног цвета ветар односи, и свилене чарапе с танким шавовима, вунени шал пада у траву, а једна за другом испадају и Мелитине ципеле. Старинске ципеле, с преклопом на дугме и лакованим бордурама. Најзад, муслинска се рекла закачи за једну гранчицу, па се тај жбун намах осу жутим цветовима; одједном надмоћан и леп. Али све су то само детаљи (88-89).

Каталог Мелитиних ствари у функцији је дочаравања њене личне трагедије, као и у функцији сликања приповедачевог опраштања с њом, као и неминовности прихватања чињенице о Мелитином страдању. На основу ритма побрајања свега што чини каталог њених ствари закључујемо да је њихово уништавање поступак који траје, да је дуг и мучан за онога који све то посматра, а који је емотивно ангажован, у личној, веома блиској, релацији с пострадалом.

Процес скупљања, а потом уништавања тих ствари процес је обесмишљавања, како Мелитиног постојања тако и свеколике људске егзистенције пред чињеницом да је зло онтолошки проблем, који се практично манифестује, и који је, како историја сведочи, цикличан, тј. вечан, као и о томе да је пред злом човек немоћан.

Као што закључујемо на основу цитираног каталога, у којем су у функцији појачавања сугестивности приповеданог употребљени метафора и персонификација, он се окончава онеобичавањем и лиризацијом приповеданог: „Најзад, муслинска се рекла закачи за једну гранчицу, па се тај жбун намах осу жутим цветовима; одједном надмоћан и леп" (89). Оба поступка у функцији су превођења приче из сфере реалистичног у сферу фантастичног.

У последњем сегменту каталога такође уочавамо библијску симболику. Призор грма за који се, приликом прикупљања јеврејских ствари, закачила Мелитина рекла - због чега се он „намах осуо жутим цветовима” (јер и сам капутић „осут жутим цветовима”) - може бити потресна симболика јеврејских жутих трака под нацистичким режимом, укључујући и окупирану Србију․․ У вези са симболиком „жбуна намах осутог жутим цветовима”, ваља подсетити и да се у библијској „Књизи изласка” (Exodus, Друга књига Мојсијева) приповеда о куйини која оїьем іори а не саїорева (неопаљива, несагорива купина) која је Мојсију омогућила богоспознају (2 Mој. 3: 2-6) ${ }^{14}$.

13 Beћ 29. априла 1941. године, тадашњи шеф војне управе у Србији, Харалд Турнер (Harald Turner), издао је наређење о обавезној регистрацији Јевреја. Наређење је почињало дефиницијом Јевреја установљеном нирнбершким законима из 1935. године, и увело је обавезно ношење жутих трака за све Јевреје на територији крње Србије под немачком окупацијом.

14 „И јави му се (Мојсију - С. И.) анђео Господњи у пламену огњеном из купине. И погледа, а то купина огњем гори а не сагорева. И Мојсије рече: Идем да видим ту утвару 
Чудесни ватрени жбун је, тако, у јудеохришћанској традицији, знак вишег созериағь, продубљенијег сазнања бивства. Зато појава жуто расцветалог грма, као места чудесне симболике на крају наведеног каталога, носи изузетну поруку теофанијске туге због масовног злочина над цивилима.

Време смрти под окупацијом, у функцији постизања уверљивости и појачавања сугестивности приповеданог, нестајање мртвачких ковчега из мртвозорничке радње, као што је раније споменуто, приповедач описује термином из света музике - глисандом:

[...] нестанак још једног ковчега, из радње Јованове [...]. Сутрадан, готово y glissandu, нестају још два ковчега, иако је читав дан протекао без гужве и пуцњаве. [...] Пети сам ковчег за тетку однео. [...] Најпосле, ту је и пуст излог погребника Јована $(87 ; 89)$.

Дакле, употребом музичког термина дочарани су трагични догађаји, узроковани ратом. Они се ређају брзо, један за другим, све док и последњи мртвачки сандук, од пет, колико их је било у излогу мртвозорничке радње, након свега неколико дана не нестане из излога.

Коначно, уочавамо и употребу гротеске чија је функција такође да ову приповетку, чија је основа реалистична, начас преведе у сферу надреалног:

Погреб је обављен скромно, у присуству неколицине избезумљених сељака, који су се врзмали међу крстачама, у потрази за храном, а можда и из навике. Појединци су, чак, доносили и стони прибор, а запажени су, додуше, и они који су, из унутрашњих џепова, помаљали и танке свећице, али их нису палили ако их нико не би гледао (89-90).

Након те гротескне слике, која не постоји у првој објављеној верзији ове приповетке, приповедач најављује долазак немачке казнене експедиције у градић: ${ }^{15}$ „С гробљанске косе пуцао је поглед на градић у који је пристизала главнина немачке оружане силе. Понадао сам се да ћу дознати штогод о Мелити. / Међутим, ништа!" (90).

велику, зашто не сагорева купина. А Господ кад га виде где иде да види, викну га Бог из купине, и рече: Мојсије! Мојсије! А он одговори: Ево ме. А Бог рече: Не иди овамо. Изуј обућу своју с ногу својих, јер је место где стојиш света земља. Још рече: Ја сам Бог оца твог, Бог Аврамов, Бог Исаков и Бог Јаковљев. А Мојсије заклони лице своје, јер га страх беше гледати у Бога" (Даничић, Караџић 1938).

15 Прва објављена верзија ове приповетке (Црни колач 1983), тј. њен завршетак, остаје у сфери реалистичног, гротескна слика налази се у наредним издањима, тај део приповетке писац је накнадно дописао. Завршетак те приповетке у првом издању гласи:

„Погреб је обављен скромно; у присуству неколицине избезумљених сељака, који су се међу крстачама врзмали, у потрази за ићем и пићем, а можда и из навике.

С гробљанске косе пуца поглед на град мали, у који пристиже немачке оружане силе главнина. Понадао сам се да ћу дознати штогод о Мелити.

Међутим, ништа!” 
Назнака о уласку Вермахта у варошицу - а тај улазак је, у контексту помињања борби по околним брдима, 1941. године, могао да значи само долазак казнене ексиеедиције (једна таква је у Краљеву, између 14. и 20. октобра 1941. године, стрељала 2.194 цивила - међу којима је било и 102 дечака и младића млађих од 18 година, као и 29 жена; а друга казнена експедиција је, у Крагујевцу између 19. и 21. октобра 1941, стрељала 2.796 цивила - међу њима и 270 деце, од којих је најмлађе имало 11 година!). Дакле, помињање уласка јединица обележених злогласним Balkenkreuz-ом („гвозденим крстом”), за српског читаоца прозе Радована Белог Марковића јесте предзнак страдања.

\section{Закључак}

Као што на основу приповеданог закључујемо, трагичност конкретног историјског времена и историјских догађаја у овој приповеци постала је детерминанта која не нарушава лепоту приповетке због начина приповедања о њима. У светлу те чињенице сагласни смо с тврђењем проф. др Витомира Вулетића да је приповедање Радована Белог Марковића „необуздана игра”'6. Њоме овај писац из садржаја животне реалности, српске и светске историје, књижевности и културе, издваја оно што је за њега значајно, али што је, посве сигурно, значајно и за све нас, што јесте саставан, важан део наше историје и традиције, а требало би да је и значајан садржај нашега бића. Због несвакидашњости поступака приповедања, специфичних структурних и стилских карактеристика, чиме остварује изузетне уметничке домете, а што смо тек у малом представили у овом раду, Радован Бели Марковић јесте најнеобичнији савремени српски писац, док је оно што је до сада написао својеврсна одбрана од заборава и самозаборава.

16 „У својој необузданој игри животном реалношћу, књижевношћу, историјом и свиме што доспе у његов видокруг он књижевно стварање уздиже до посла надмоћног над животом, надмоћног јер зауставља живом речју, сликом и тоном оно што у животу буде и оде у неповрат. Снага истинске уметности, по њему, и у томе је што у животу открива оно што се обичном оку не да, што обично уво не чује. То што је у овој књизи живот гомила крхотина не значи да је овај писац безнадежни очајник, који је доспео до апсолутне тачке сазнања да је све бесмислено. Већ то да нам о тим крхотинама прича необичним језиком и упечатљиво нас уверава да у овом животу постоји нешто о чему има смисла причати" (Вулетић 2005). 


\section{ЛИТЕРАТУРА}

Вулетић, Витомир. Раgован Бели Марковић: сииилске и језичке иіре. Ваљево: Колубара, 2005.

Даничић, Ђуро, Караџић Стефановић, Вук. Свет̄о йисмо Сӣароїа и Новоїа завјейа. Биоград: Издање британскога и иностранога библијскога друштва, 1938.

Еко, Умберто. Бескрајни сиичскови (Umberto Eco, Vertigine della lista, 2009). С италијанског превео Александар В. Стефановић. Београд: Плато, 2011.

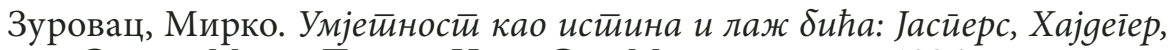

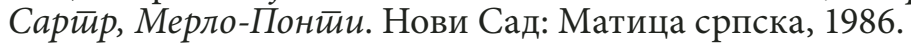

Караџић, Вук Стефановић. Срйски рјечник: исиуумачен юемачкијем и латиинскијем ријечима. Беч: Штампарија јерменскога намастира, 1852.

Лексикон музичке уметности. Енциклойеgијски тексикон: мозаик

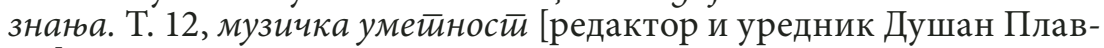
ша]. Београд: Интерпрес, 1972.

Марковић, Бели Радован. Црни колач. Ваљево: „Милић Ракић”, 1983.

Марковић, Бели Радован. Ћорава сиирана, изабране и нове приче. Београд: СКЗ, 2007.

Марковић, Бели Радован. Сабрана gела, књига 4. Лајковац: Градска библиотека, 2013.

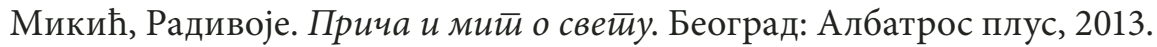

Речник срйскохрватискоїа книжевной језика. Нови Сад: Матица српска. Загреб: Матица хрватска, том: 1-6.

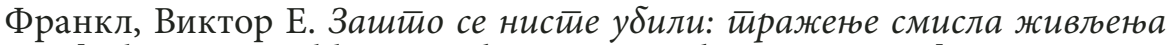
[Viktor E. Frankl, ... trotzdem Ja zum Leben sagen, 1946]. Преводилац Вера Весковић Албуљ. Београд: „Жарко Албуљ”, Лута: Монада, 1994.

Slađana Ilić

The Lyric Rendering of History in the Story „Melita, kovčezi, ostalo“

Summary

The short story „Melita, kovčezi, ostalo” (1983) by Radovan Beli Marković (1948) is the only one in the oeuvre of this writer that depicts the pogrom of Jews in the occupied Serbia during World War II as one of its most important topics. It is interesting, inter alia, because it contains elements of the political discourse and is narrated in a lyrical tone. The narrator uses some musical terms to conjure up the sequence of events. The structure of the narration has the same function, as well. 
The way of achieving a lyrical tone in the story is also impressive: by using tropes, some syntactic interventions, grotesque, biblical symbolism, catalogues, as well as the process of transferring the reality-based story to the unusual and mystic, etc. With these literary tools, the tragedy of historical events becomes the determinant which doesn't damage the beauty of the story. At the same time, it allows a reader to experience the truth of an epoch through the destinies of the characters - ordinary people - more profoundly and more thoroughly than by reading the historiographical and sociological texts.

Keywords: pogrom, Jews, World War II, political discourse, lyrical tone, glissando, fugue, narration, stylistic devices, grotesque 